Araştırma Makalesi - Research Article

\title{
Nanoparçacık Eklenmesi ile Metakrilat Esaslı Kontak Lenslerin Mikromekanik ve Optik Özelliklerinin Geliştirilmesi
}

\author{
Mine ŞENER ${ }^{1}$, Mustafa Oğuzhan ÇAĞLAYAN ${ }^{2 *}$ \\ Geliş / Received: 26/05/2019 \\ Revize / Revised: 28/11/2019 \\ Kabul / Accepted: 03/12/2019 \\ ÖZ
}

\begin{abstract}
Atomik kuvvet mikroskobisi (AFM) ve kuvvet spektroskopisi (FS) malzemenin mekanik özelliklerinin nanoölçekte belirlenmesini sağlayan bir yöntemdir. Bu çalışmada, birinci nesil kontak lens malzemesi olan metakrilat (MA) temelli kopolimerler kullanılarak üretilen lenslerin mekanik ve optik özelliklerinin geliştirilmesi amaçlanmıştır. Farklı içeriklerde ve farklı çapraz bağlanma oranlarında üretilen kontak lenslere in situ polimerizasyon süreci ile nanoparçacık ilave edilmiş ve mekanik testleri AFM kullanılarak gerçekleştirilerek elastik davranışları incelenmiştir. Nanoparçacık ilavesi ile değişen optik özellikler ise elipsometre kullanılarak karakterize edilmiştir. Düşük miktarlarda (kütlece \%2'den az) nanoparçacık ilavesi ile elastik deformasyon özelliklerinde 2 kat kadar artış ve özellikle UV bölgede ışık soğurum oranında artış elde edilmiştir. MA neslinden olan (1. Nesil) lenslerin, üretim yönteminde büyük değişiklikler yapılmaksızın daha yüksek dayanım ve olumlu optik özellikler içerecek şekilde üretilmesinin mümkün olduğu kanıtlanmıştır.
\end{abstract}

Anahtar Kelimeler-Metakrilat Esaslı Lensler, Hidrojel, Nanoparçacık Katkılama, Mikromekanik Test, Atomik Kuvvet Mikroskobisi, Kuvvet Mikroskobisi, Elipsometri

\footnotetext{
2*Sorumlu yazar iletişim: oguzhan.caglayan@bilecik.edu.tr, (https://orcid.org/0000-0002-7265-1094) Bilecik Șeyh Edebali Üniversitesi Biyomühendislik Bölümü, Bilecik, Türkiye 1İletişim: minesenerr@gmail.com, (https://orcid.org/0000-0003-1617-5887)

Cumhuriyet Üniversitesi Kimya Mühendisliği Bölümü, Sivas, Türkiye
} 


\title{
Improvement of micromechanical and optical properties of methacrylate based contact lenses by addition of nanoparticles
}

\begin{abstract}
Atomic force microscopy (AFM) and force spectroscopy (FS) is a method of determining the mechanical properties of the material in nanoscale. In this study, it is aimed to improve the mechanical and optical properties of lenses made of methacrylate (MA) based copolymers which are first-generation contact lens material. The nanoparticle was added to the contact lenses produced having different contents and at different crosslinking rates by in situ polymerization process. The optical properties changed by the addition of nanoparticles were characterized by using an ellipsometer. With the addition of low amounts of nanoparticle (less than $2 \%$ by mass), an increase in elastic deformation properties by 2 times and an increase in the rate of light absorption in the UV region were obtained. It is proven possible that the MA generation (1st Generation) lenses can be produced with higher mechanical strength and positive optical properties without major changes in the production method.
\end{abstract}

Keywords- Methacrylate Based Lenses, Hydrogel, Nanoparticle Doping, Micromechanical Testing, Atomic Force Microscopy, Force Microscopy, Ellipsometry 


\section{I.GİRIŞ}

\section{A. Kontak Lensler ve Üretiminde Kullanılan Materyaller}

Halen üretilmekte olan 1. nesil kontak lensler ile göz içi lensler, genelde metakrilat (MA) temelli kopolimerler esas alınarak üretilmektedir. Biyouyumlu polimer türlerinden olan polimetilmetakrilat (pMMA), polihidroksietilmetakrilat (pHEMA) ve polietilenglikoldimetakrilat (pEGDMA) ile bunların çapraz bağlı kopolimerleri, bu tür lens malzemelerinin üretiminde kullanılmaktadır [1]. Işık geçirgen, sert ve kararlı olan pMMA doğrusal yapıda zincir polimeridir ve hidrofobiktir [2]. Kopolimerlerinde HEMA, malzemeye yumuşaklık kazandırdığ 1 için genellikle yumuşak kontak lens yapımında kullanılır. Metil metakrilata metilol $\left(-\mathrm{CH}_{2} \mathrm{OH}\right)$ grubunun eklenmesi ile 2-hidroksietilmetakrilat (HEMA) oluşur. Hidrojel formda olan yumuşak kontak lensler, pHEMA'nın EGDMA ile çapraz bağlanması sonucu hazırlanır. Kullanım yerine göre, malzemeye sertlik vermek için yapıya MMA ilave edilir [3]. pMMA sert kontakt lens yapımında kullanılan ilk malzeme olmuştur ve en önemli avantajları, hafifliği, yüksek 1slanabilirliği, şeffaflığı, uzun süre kullanılabilirliği ve çizilmeye karşı dayanıklılığıdır. Floropolimer lensler (2. Nesil) siloksan materyali veya silikon olmayan polimerli florlanmış monomer içermektedirler. florometilmetakrilat ya da florosilikonakrilat monomerlerden elde edilirler. Yeni nesil lens malzemesinin ıslanabilirliği iyidir, ayrıca bükülmeye dayanıklıdır [4].

Hidrofilik monomerlerin polimerizasyonu ya da kopolimerizasyonu ile yumuşak lensler elde edilir. pMMA ve pHEMA su ile şişmediklerinde sert camsı karakterlere sahiptir. Ortama su eklendiğinde malzemenin plastik özelliği artarken aynı zamanda lubrikasyon da artar [5]. Bu kopolimerlerin çapraz bağ sıklığı malzemenin elastik karakterini belirler. Bu çalışmada lens malzemeleri deney numuneleri, farklı oranlarda çapraz bağlı ve film döküm tekniği ile hazırlanmıştır. Ticari kontak lenslerin üretiminde kullanılan yöntemlerden biri döküm kalıplamadır [6]. Kullanım açısından yumuşak ve çok su içeren lens malzemeleri konfor sağlarken, mekanik dayanım bir sorun haline gelmektedir. Bu nedenle, çok su içerikli ve yumuşak lensler tek kullanımlık (günlük) lensler olarak kullanılmaktadır. Bazı lens malzemelerinin elastik modül $(E)$ değerleri Tablo 1'de verilmiştir.

Tablo 1. Bazı lens malzemelerinin ve ham maddelerinin elastik modül değerleri [7].

\begin{tabular}{ll}
\hline Malzeme & $\boldsymbol{E}(\mathbf{M P a})$ \\
\hline pMMA & 2000 \\
Lotrafilcon A & 1.5 \\
Balafilcon A & 1.1 \\
Silikon kauçuğu & 0.80 \\
Senofilcon A & 0.72 \\
Vifilcon A & 0.51 \\
pHEMA & 0.50 \\
Omafilcon A & 0.49 \\
\hline
\end{tabular}

\section{B. Nanoindentasyon ve Kuvvet Spektroskopisi}

Malzemenin sertlik ve elastik modülünün ölçülmesinde indentasyon (batırma) tekniği, küçük ölçeklerdeki malzemelerin mekanik özelliklerinin karakterizasyonunda kullanılmaktadır [8]. Yüksek çözünürlüğe sahip test ekipmanları ile mikrometre ve nanometre ölçeklerde mekanik özellikleri ölçmek oldukça kolaydır. Bu nedenle, ince filmlerin ve küçük yapıların mekanik özelliklerinin belirlenmesinde kullanılan bir teknik haline gelmiştir. Filmlerin karakteristik kalınlıkları $1 \mu \mathrm{m}$ civarındadır ve bu teknik kullanılarak mekanik testler gerçekleştirilebilir. Ayrıca nanoindentasyon, birkaç nanometre incelikte filmlerin karşılaştırılmasında ve karakterize edilmesinde de kullanılmaktadır [9]. İndentasyon tekniğinde yüke bağlı olarak daldırma ucundaki yer değiştirme gözlemlenir. Bu yük-derinlik verileri sertlik, elastiklik modülü, akma mukavemeti, sertleşme üsteli, kırılma tokluğu gibi elasto- 
plastik özelliklerin belirlenmesini sağlamaktadır. Ancak uygun yöntemler kullanılmadığında, boyut ve yüzey etkisi nedeniyle mikro/nano ölçek altındaki mekanik özellikler makro ölçekteki özelliklerden farklı olabilir [10]. Nanoindentasyon yöntemi, katı maddeler ve ince filmlerde mekanik özellikleri belirlemek için yaygın olarak kullanılmaktadır. Yük-derinlik eğrisinden elastik özelliklerin belirlenmesinin yanı sıra, sertlik de ölçülebilmektedir [11].

Kuvvet spektroskopisi (FS) analizi, Atomik Kuvvet Mikroskobunda (AFM) uygulanan bir nanoindentasyon tekniğidir. Bu teknikte AFM probu, $\mu \mathrm{N}$ ile birkaç $\mathrm{pN}$ arasında dikey kuvvetler uygulayabilen bir indenter olarak kullanılır. Bu işlem sırasında AFM probu numune yüzeyinden içeriye doğru belirli bir $\Delta z$ mesafesinde itilir, etkileşim gerçekleştirdikten sonra da AFM probu yeniden başlangıç pozisyonuna getirilir. $\mathrm{Bu}$ işlem yüksek bir kuvvet çözünürlüğünde tüm malzemeler için nanomekanik ölçümler sağlar [12]. Numune yüzeyine uygulanan kuvvet (F) arttırıldıkça numuneye baskı uygulanır ve numune hem elastik hem de plastik deformasyona uğrayabilir.

Nanoindentasyon cihazı olarak AFM'nin en temel sorunu AFM ucunun gerçek çapının ölçülememesidir [13]. Nanoindentasyon işleminde AFM kullanımının birçok avantajı bulunmaktadır. Örneğin, ölçümler oldukça lokaldir (numune ve prob arasında birkaç $\mathrm{pm}^{2}$ 'lik küçük temas alanı bulunur) ve farklı alanlarda ölçüm gerçekleştirilerek, numuneye ait mekanik özelliklerin ortalamasının alınması sağlanabilir [14]. Ayrıca, bu yöntem derinliğe bağlı bir algılama sağlar ve farklı daldırma derinliklerinde bir malzemenin karakterizasyonunun gerçekleştirilmesine olanak tanır [15]. Son olarak, indentasyon testleri sırasında oluşan baskı izinin görüntülenmesi ve karakterize edilmesi gerekmez ki bu işlem $E$ modülünün hesaplanmasını kolaylaştırır. Nanoindentasyon işleminde birkaç nN'dan $\mathrm{pN}$ seviyesine kadar değişen yükler uygulanarak $E$ modülü güvenilir bir şekilde belirlenebilmektedir [16]. Kuvvete karşılık yer değiştirme eğrileri (F-z), bu eğrilerin klasik makro veya mikroindentasyon testlerinden elde edilen eğriler ile benzerlik gösterir. Ölçüm sırasındaki farklar yalnızca ölçek ile ilgilidir. Örneğin, AFM ucu yüzeye yaklaşırken çekim yönündeki van der Waals kuvvetleri su menisküsü veya elektrostatik kuvvetler nedeni ile uç aşağıya doğru bükülür. Ardından numune yüzeyi ile tip yüzeyi arasındaki sert temas nedeniyle AFM ucu yukarı doğru esner ve numune elastik olarak sıkıştırılır. Burada gerçekleşen süreç diğer indentasyon ölçeklerindeki ile aynıdır. Ardından, yükün geri alınması işleminde AFM ucu ile numune arasında adhezyon kuvvetleri diğer yöntemlere oranla daha etkin olur [17]. Sonuç olarak, sert AFM ucu ile gerçekleştirilen indentasyon, yumuşak bir örnek için (Young modülü $E$, Poisson oranı $v$ ve yay sabiti, $k$ değerleri bilindiğinde) Hertzian temas mekaniği kullanılarak modellenebilir [18].

Bu çalışmada, kontak lens ana malzemesi olarak metakrilat esaslı kopolimerlerin mekanik davranışları incelenmiş, bu kopolimerlere farklı oranlarda nanoparçacık ilave edilerek mekanik performansları değerlendirilmiştir. Ayrıca, Ag nanoparçacık kullanılarak, optik performanstaki değişim incelenmiştir.

\section{II.MALZEME VE YÖNTEM}

\section{A. Kullanilan Kimyasal Maddeler ve Cihazlar}

Polimer sentezinde kullanılan HEMA ve MMA monomerleri, çapraz bağlayıcı olarak kullanılan EGDMA monomeri, başlatıcı olarak kullanılan benzoil peroksit (BPO) (Sigma-Aldrich, ABD) satın alma yolu ile temin edilmiş ve ilave saflaştırma işlemi yapılmadan kullanılmıştır. Titanyum oksit $\left(\mathrm{TiO}_{2}\right)$ nanoparçacıkları $\left(\mathrm{TiO}_{2}\right.$, rutil, $_{\text {, }}$ $165 \mathrm{~nm}$, küresel) ve çinko oksit (ZnO, 35-45 nm, küresel) nanoparçacıkları satın alma yolu ile temin edilmiştir (US Research Nanomaterials, Inc., ABD). Deneylerde kullanılan Ag nanoparçacıklar (ortalama $25 \mathrm{~nm}, \mathrm{kür} e s e l$ ), US Research Nanomaterials, Inc.'den (ABD) satın alınmıştır. Belirtilen kimyasallar (BPO hariç) ve nanoparçacıklar ilave bir saflaştırma işlemine tabi tutulmadan temin edildiği şekli ile kullanılmıştır. BPO, reaksiyon öncesi kurutularak kullanılmıştır.

Dispersiyon ve homojenizasyon işlemleri için Jeio-Tech marka US-P (Kore) model ultrasonik banyo kullanılmıştır. Hazırlanan sıvı numunelerin polimerizasyon işlemi Jeio-Tech marka BW-10H model (Kore) sıcaklık kontrollü 1sıtmalı su banyosunda tamamlanmıştır. Ayrıca tüm deneyler boyunca yıkama işlemi için deiyonize su kullanılmıştır. Daha sonra yüzeydeki kirlilikleri ve kalan monomer kalıntılarını uzaklaştırmak için etil alkol (\% 99 v/v) ile birkaç kez banyo edilmiştir. Polimerlerin kurutma işlemi ise etüv kullanılarak yapılmıştır. 
Hazırlanan örneklerin üç boyutlu görüntüleri Park System marka XE 100 model (Kore) Atomik Kuvvet Mikroskobu (AFM) cihazı kullanılarak elde edilmiştir. Elastik modül, indentasyon eğrisindeki doğrusal (elastik deformasyon) bölge kullanılarak Hertzian temas mekaniğine göre hesaplanmıştır [18].

\section{B. Polimerlerin Sentezi ve Karakterizasyonu}

İlk olarak çapraz bağlı polimer sentezi için gerekli olan HEMA monomeri ve MMA monomeri farklı hacim oranlarında karıştırılmış ve her bir numune üzerine farklı hacim oranlarında uygun çapraz bağlayıcı olan EGDMA eklenmiştir. $\mathrm{Bu}$ işlemin ardından farklı hacim oranlarında monomer içeren sıvı numunelere polimerizasyon için gerekli başlatıcı olan BPO ilave edilmiştir. Numuneler MxCy şeklinde kodlanmıştır. M0, yalnızca HEMA- EGDMA kopolimerini göstermektedir. Mx, kütlece yüzde cinsinden kopolimerdeki MMA miktarını, Cy ise kütlece yüzde cinsinden EGDMA miktarını göstermektedir. Tüm sentezlerde 0.01 g BPO ve 2 $\mathrm{mL}$ etanol kullanılmıştır. Başlatıcının homojen olarak çözünmesi için, her bir çözelti 5 dakika ultrasonik banyoda içerisinde bekletilmiştir. Çapraz bağlama işlemi, $80^{\circ} \mathrm{C}$ 'ta 2 saat olarak gerçekleştirilmiştir. Sentezlenen çapraz bağlı polimer filmler, monomer ve başlatıcı kalıntılarının uzaklaşması amacı ile etanol içerisinde bekletilmiştir. $\mathrm{Bu}$ işlemin sonunda her bir polimer film $40^{\circ} \mathrm{C}$ sicaklıkta 1 gün boyunca kurutulmuştur.

\section{Nanopartikül İçeren Polimerlerin Sentezi}

Nanoparçacıkların mekanik özelliklere etkisi M20C5 (\%20 MMA ve \%5 EGDMA içeren) kopolimer üzerinde test edilmiştir. Boyutları ve miktarları farklı nanoparçacık olarak $\mathrm{TiO}_{2}$, Ag ve $\mathrm{ZnO}$ kullanılmıştır. Belirlenen monomer oranlarında malzemenin elastik-plastik özelliklerine etkisinin incelenmesi amacıyla nanopartikül içeren polimerler, nanoparçacıkların polimerizasyon sırasında yapıya eklenmesi ile (in situ) sentezlenmiştir. Nanoparçacık miktarı 0.02, 0.01, 0.002, 0.001 ve $0.0002 \mathrm{~g}$ olmak üzere ilave edilmiş ve en yüksek derişim NP5 olacak şekilde NPz şeklinde isimlendirilmiştir. Örneğin T5, $0.02 \mathrm{~g}$ (yaklaşık \%1 m/m) TiO 2 içeren numunedir.

\section{III.BULGULAR VE TARTIŞMA}

\section{A. AFM Topografisi ve Yüzey Karakterizasyonu}

AFM görüntüleri her bir polimer filmden $5 \mu m \times 5 \mu m$ yüzey alanında elde edilmiştir ve genel olarak kopolimerin yüzey pürüzlülüklerinin yüksek olduğu görülmektedir. Örneğin M0C60 olarak adlandırılan numunede \pm 95 nm yükseklik farkı elde edilirken, oldukça küçük tanecikli yüzey şekilleri de dikkati çekmektedir. Çapraz bağlı HEMA-MMA kopolimer filmlerine ait AFM görüntüleri Şekil 1'de verilmiştir. Genel olarak, polimerizasyon sırasında küçük hataların oluştuğu ancak polimerik yapıya uygun bir topografi elde edildiği görülmektedir. Çapraz bağlayıcı oranının artması ile yüzey pürüzlülüğü artmaktadır.

\section{B. Nanoparçacık İçeren Polimerlerin AFM Topografisi}

Şekil 2'de $\mathrm{TiO}_{2}$ ve $\mathrm{ZnO}$ nanopartikülleri içeren çapraz bağlı HEMA-MMA kopolimer filmlerine ait AFM görüntülerine örnekler verilmiştir. Film içerisinde dağılımı az olan nanopartiküller yüzeyde birikinti oluşturarak geniş yükseklik dağılımı sergilemiştir. Oysaki düşük derişimlerde, özellikle de T1 olarak adlandırılan numunede yüzey oldukça pürüzsüzdür, yalnızca bir iki bölgede (şekilde parlak bölge) yüzey formasyonu 15-20 nm civarında olmuştur. 


\begin{tabular}{|c|c|c|}
\hline & $\begin{array}{l}\text { BŞEÜ Fen Bilimleri Dergisi } \\
6(2), 210-220,2019\end{array}$ & $\begin{array}{r}\text { BSEU Journal of Science } \\
\text { DOI: } 10.35193 / \text { bseufbd.570256 }\end{array}$ \\
\hline $\begin{array}{l}\text { BIIECEKSEYHEEEBALI } \\
\text { UNIVERSITESI }\end{array}$ & & e-ISSN: 2458-7575 (http://dergipark.gov.tr/bseufbd) \\
\hline
\end{tabular}

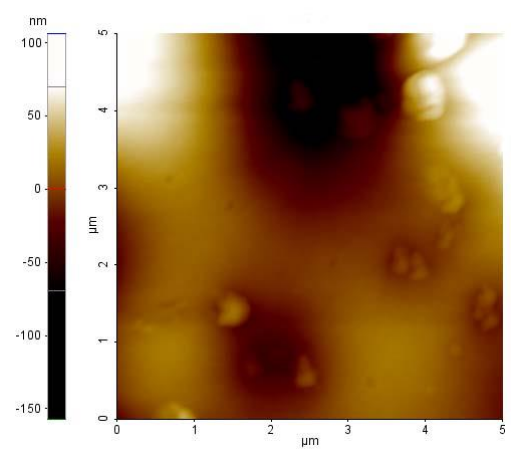

(a)

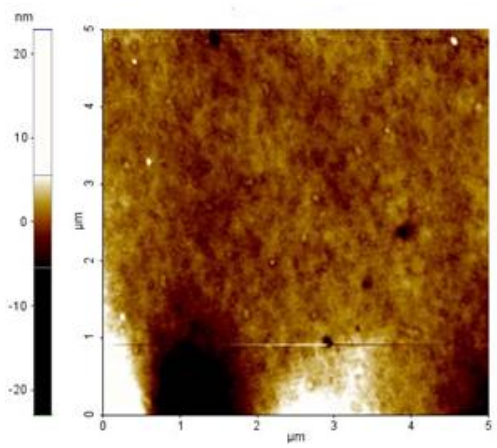

(c)

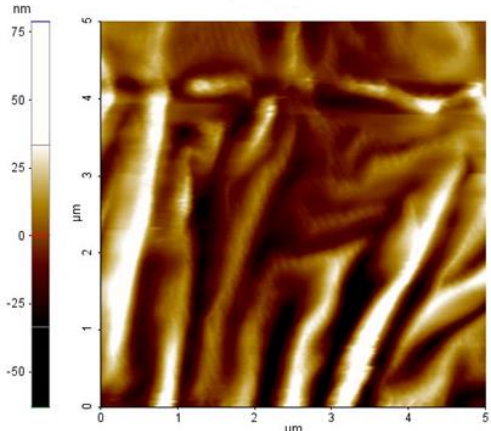

(e)

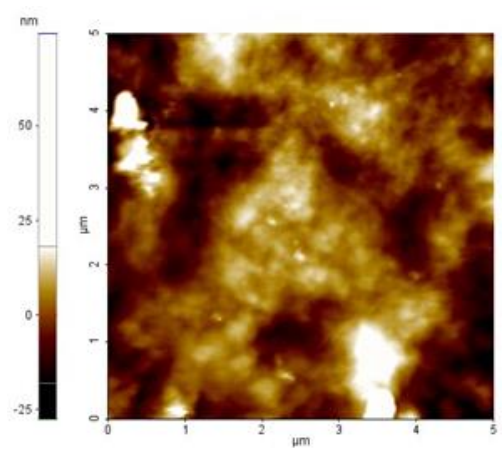

(b)

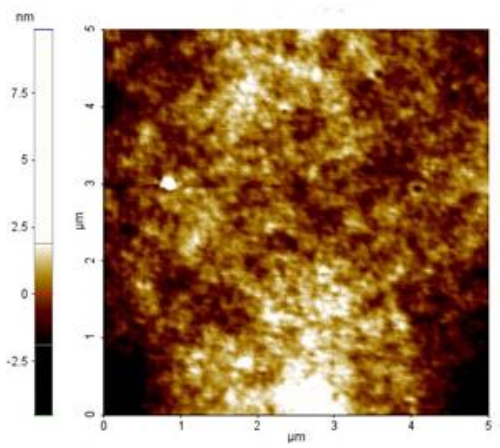

(d)

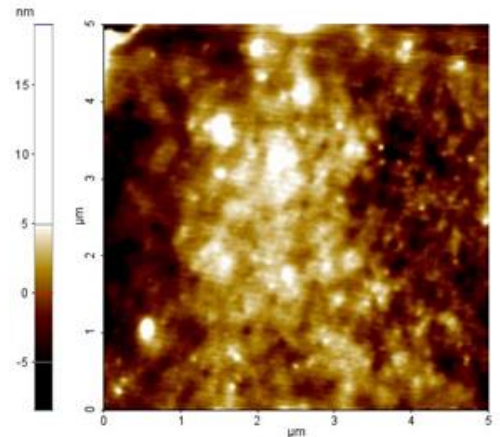

(f)

Şekil 1. M0C5 (a), M0C60 (b), M20C5 (c), M20C60 (d) , M30C5 (e) ve M30C60 (f) olarak adlandırılan polimer filmlerin AFM topografisi. (tüm AFM ölçümleri $5 \mu \mathrm{m}$ x $5 \mu \mathrm{m}$ tarama alanından alınmıştır. Yükseklik ölçeği en yüksek değerleri sırasıyla a) $\sim 100 \mathrm{~nm}, \mathrm{~b}$ ) 70 nm, c) 20 $\mathrm{nm}, \mathrm{d}) \sim 10$ ve e) 75 ve f) $\sim 20 \mathrm{~nm}$ 'dir.)

Z1 filminin düzenli ve homojen dağılıma sahip olduğu görülmektedir. Z5 numunesinde yüksek ZnO nanopartikül derişimi nedeniyle $\mathrm{ZnO}$ nanoparçacıkların yüzeyde kümelendiği görülmektedir. $\mathrm{TiO}_{2}$ ile karşılaştırıldığında ZnO nanoparçacıkların HEMA-MMA polimer içerisinde çok daha iyi dağıldığı söylenebilir.

\section{Indentasyon Deneyleri}

Numunelere ait $E$ modülü, FS deneylerinden elde edilmiştir. Nanoparçacık ilave edilmiş olan numunelere ait bu değerler, FS eğrilerinin doğrusal kısımlarından elde edilen verilerden hesaplanmıştır [19-21]. Numune 


\begin{tabular}{|c|c|c|}
\hline & $\begin{array}{l}\text { BŞEÜ Fen Bilimleri Dergisi } \\
6(2), 210-220,2019\end{array}$ & $\begin{array}{r}\text { BSEU Journal of Science } \\
\text { DOI: } 10.35193 / \text { bseufbd.570256 }\end{array}$ \\
\hline $\begin{array}{l}\text { BIIECIISEYYEDEBALI } \\
\text { ONIVERSITESI }\end{array}$ & & e-ISSN: 2458-7575 (http://dergipark.gov.tr/bseufbd) \\
\hline
\end{tabular}

başına en az 50 noktada gerçekleştirilen indentasyon işlemi sonucu $\mathrm{TiO}_{2}$ ihtiva eden numunelerde $E$ modülü (Young modülü) değerlerinin değişimi Şekil 3’te verilmiştir.

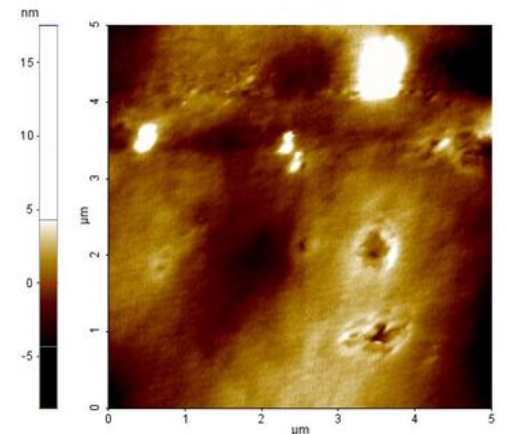

(a)

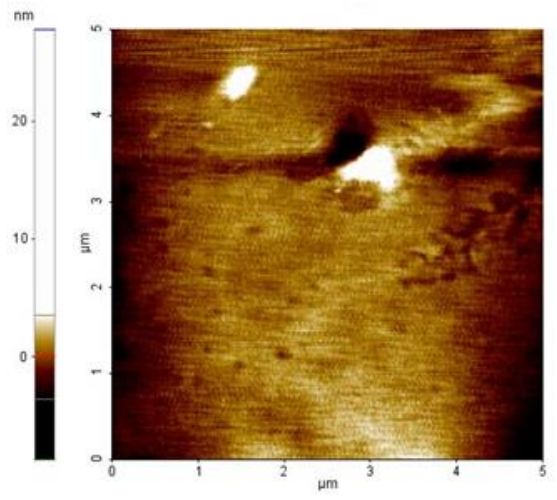

(c)

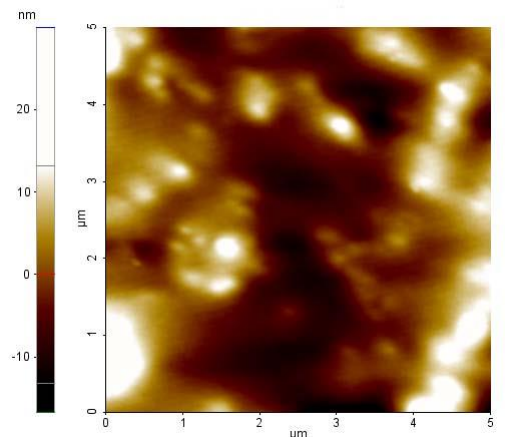

(b)

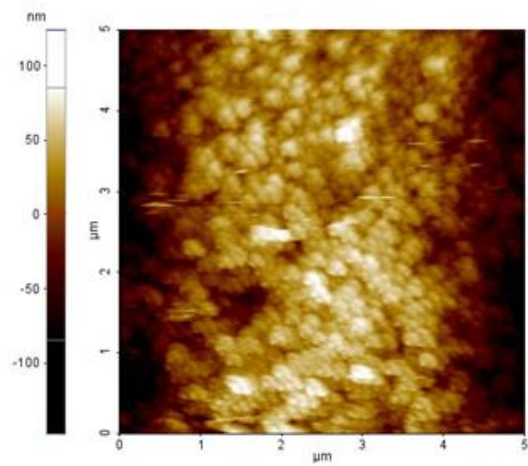

(d)

Şekil 2. T1 (a), T5 (b), Z1 (c) ve Z5 (d) olarak adlandırlan nanopartikül içeren polimer filmlerin AFM topografisi (tüm AFM ölçümleri $5 \mu \mathrm{m}$ x $5 \mu \mathrm{m}$ tarama alanından alınmıştır. Yükseklik ölçeği en yüksek değerleri sırasıyla a) $\sim 15 \mathrm{~nm}$, b) $\sim 30 \mathrm{~nm}, \mathrm{c}$ ) $30 \mathrm{~nm}$ ve d) 120 nm'dir.)

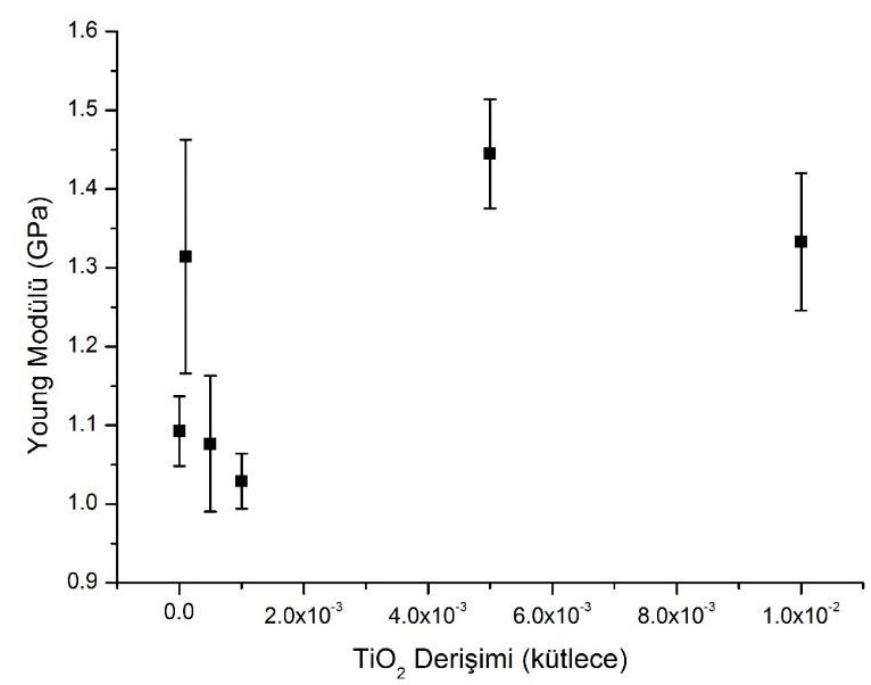

Şekil 3 - $\mathrm{TiO}_{2}$ nanoparçacık içeren $\mathrm{M} 20 \mathrm{C} 5$ numunesine ait Young Modülü değerlerinin $\mathrm{TiO}_{2}$ derişimi ile değişimi. 
Şekil 3'te görüldüğü üzere, $\mathrm{TiO}_{2}$ derişiminin artması ile $E$ modülünde anlamlı bir değişim gözlenememiş ancak $E$ modülü M20C5 numunesine oranla kayda değer oranda artmıştır. E değeri, M20C5 numunesinde $1 \mathrm{GPa}$ civarında iken, kütlece $\% 0.5$ oranında $\mathrm{TiO}_{2}$ ihtiva eden numunede $1.4 \mathrm{GPa}$ değeri civarına yükselmiştir. Genel olarak, anlamlı bir değişim gözlenememesi, $\mathrm{TiO}_{2}$ nanoparçacıkların HEMA-MMA-EGDMA çapraz bağlı kopolimer içerisinde yeterince uniform dağılmaması nedeniyledir. Monomer fazlarından birisi içerisine dağıtılan nanoparçacıklar, polimerizasyon devam ederken bir araya gelerek uniformluğu bozmaktadır. ZnO içeren numunelerdeki $E$ modülü değişimi ise, Şekil 4'te verilmiştir.

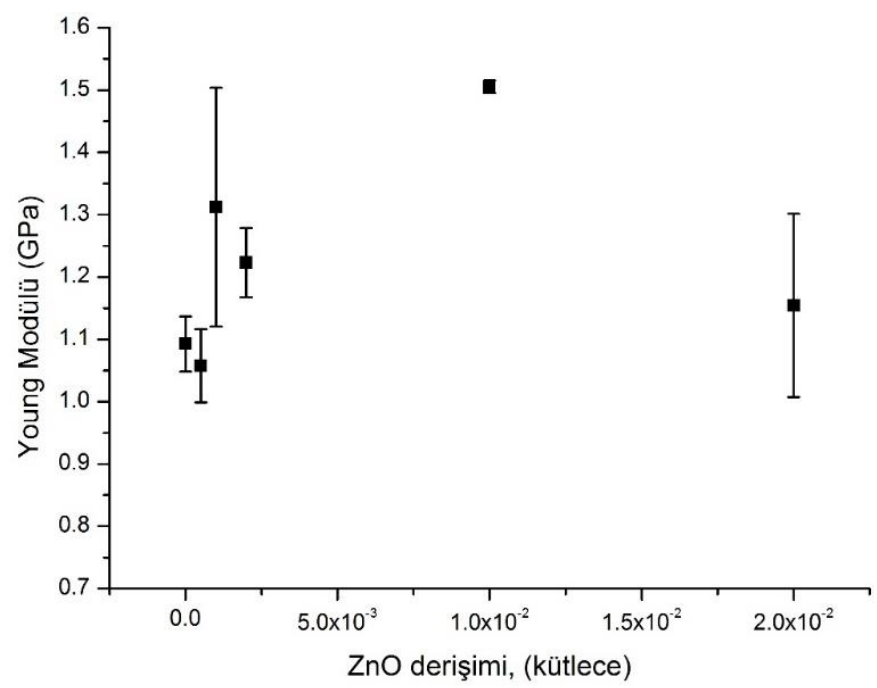

Şekil 4 - ZnO nanoparçacık içeren M20C5 numunesine ait Young Modülü değerlerinin ZnO derişimi ile değişimi.

Şekil 4'te görüldüğü üzere, $\mathrm{ZnO}$ derişiminin artması ile kütlece \%1 oranında $\mathrm{ZnO}$ derişimine kadar $E$ modülünde anlamlı bir artış gözlenmiştir. $E$ modülü M20C5 numunesinde 1GPa civarında iken \%1 ZnO ihtiva eden numunede $1.5 \mathrm{GPa}$ civarına yükselmiştir. $E$ modülü, $\% 2 \mathrm{ZnO}$ derişimde azalarak HEMA-MMA-EGDMA çapraz bağlı kopolimerin elastik modül seviyesine inmiştir. ZnO içeren kopolimer numunelerinde uniform dağılım elde edilebildiğinden, nanoparçacık ilavesinin anlamlı bir şekilde elastik modülü artırdığı görülmüştür. ZnO nanoparçacıkların uygun bir şekilde HEMA-MMA-EGDMA çapraz bağlı kopolimeri içerisinde dağıtılması, muhtemelen $\mathrm{ZnO}$ nanoparçacıkların boyutunun daha küçük olmasından kaynaklanmaktadır. Bu şekilde dağılım sonucu kütlece \%0.01 oranında $\mathrm{ZnO}$ ilave edilmesinde bile E değeri $1 \mathrm{GPa}$ 'dan $1.3 \mathrm{GPa}$ 'a artırılmıştır.

Genel olarak, TiO2 ve ZnO nanoparçacıkların, HEMA-MMA-EGDMA çapraz bağlı kopolimeri içerisine katılması ile elde edilen numunelerde elastik modülün arttığı görülmüştür. Ayrıca, yüzeyler ile AFM ucu arasındaki van der Waals etkileşimlerinin artması, nanoparçacık ilavesi ile yüzeyin nispeten hidrofilik yapıya kaydığı da görülmüştür. AFM ucu ile yüzey arasındaki adezyon kuvvetleri ise, nanoparçacık ilavesi ile azalmaktadir.

Nanoparçacık dağılımının, polimer matrisi içerisinde uniform bir şekilde yapılabildiği çapraz bağlı kopolimer- nanoparçacık kompozitlerinde, düşük derişimde nanoparçacık ilavesinde bile elastik modülde artış gözlenmektedir. Ayrıca, uniform dağılımlı nanopartikül olan polimer filmlerde, yüzey pürüzlülügünün de düşük olduğu görülmüştür. Yine benzer şekilde, düşük miktarlarda nanoparçacık ilavesi ile yüzey özellikleri değiştirilebilmektedir.

\section{Kırınım İndisi ve Soğurum Özellikleri}

Farklı miktarda nanoparçacık içeren malzemelerin kırınım indisleri ölçümü elipsometre kullanılarak gerçekleştirilmiştir. Kırınım indisi, nanoparçacık derişimi arttıkça artmaktadır (Şekil 5.a). Nanoparçacık

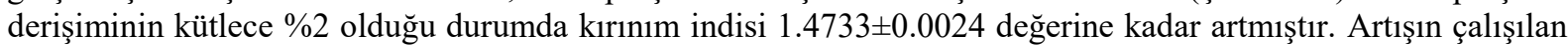


aralıkta doğrusal çıkması $\left(\mathrm{R}^{2}=0.99\right)$, lens içerisine Ag eklendikçe kontak lensin kırınım indisinin istenildiği gibi değiştirilebileceğini göstermektedir. Ayrıca 1şık geçirgenlikteki değişim, mor ötesi ve görünür 1şık tayfta elipsometre kullanılarak belirlenmiştir. Ag nanoparçacığın \%2 kütlesel derişimde teorik geçirgenlik eğrisi, MieHaes teorisine göre [22] hesaplanmıştır ve Ag nanoparçacık ilave edilmiş kontak lensin özellikle $400 \mathrm{~nm}$ ve altında yüksek soğurum verdiği görülmüştür. \%1 ve \%2 kütlesel derişimde Ag nanoparçacık içeren polimerler için mor ötesi ve görünür bölge tayfinda geçirgenlik değişimi Şekil 5(b)'de verilmiştir.

Farklı derişimlerde Ag nanoparçacık içeren kopolimerin kırınım indisi, doğru orantılı bir şekilde artmıştır. \%2'ye kadar Ag nanoparçacık içeren kopolimerde, Ag nanoparçacıkların dağılımı nispeten düzgün bir şekilde yapılabilmiştir. Çalışmanın bir diğer avantajlı yönü, beklendiği üzere, üretilen Ag katkılı kontak lenslerin özellikle UV bölgede düşük 1şık geçirgenliğine sahip olmasıdır. Güneş 1şınlarından gelen ve göze zararı olan yüksek enerjili UVA ve UVB ışınlarının büyük oranda soğurulduğu görülmektedir. Mor bölgede (400 nm üzeri) gerçekleşen soğurum ise, Ag nanoparçacıkların boyutunun değiştirilmesi ile düzeltilebilir.

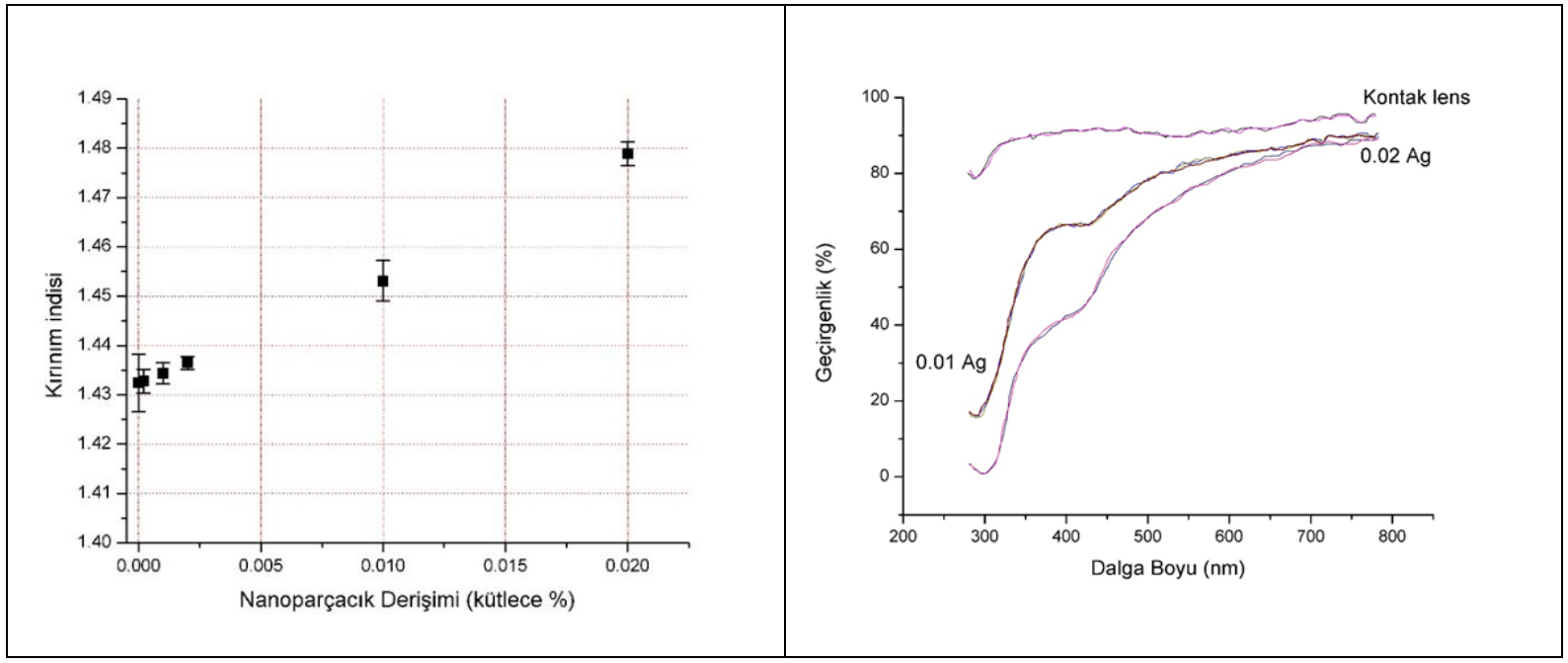

Şekil 5 - Farklı miktarlarda Ag nanoparçacık ilave edilmiş kontak lensin kırınım indisindeki değişim (a) ve sentezlenen kontak lensin 0.01 Ag ve $0.02 \mathrm{Ag}$ için geçirgenlik değişimi (b).

\section{SONUÇLAR}

Bu çalışmada, 1. Nesil olan ancak halen göz içi ve kontak lens olarak üretimi gerçekleştirilen MA esaslı kopolimer hammaddeli kontak lenslerin mekanik ve optik özelliklerinin iyileştirilmesi araştırılmıştır. Farklı monomer ve çapraz bağlayıcı oranlarında üretilen filmlerde, çapraz bağlanma oranı arttıkça malzemenin elastik modülünün arttığı (200 MPa- 1GPa) ancak yapının daha az uniform hale geldiği görülmüştür. Farklı oranlarda $\mathrm{ZnO}$ ve $\mathrm{TiO}_{2}$ nanoparçacık içeren MMA-HEMA-EGDMA kopolimeri ise, daha yüksek elastik modül sağlamış ve $\mathrm{ZnO}$ için oldukça uniform bir dağılım da göstermiştir. Antibakteriyel özelliği bilinen Ag nanoparçacıklarının yapıya ilavesi ile optik özelliklerde teorik olarak belirlenen $400 \mathrm{~nm}$ civarında soğurum ile UV geçirgenliğin azaltılması hedeflenmiştir. Sentezlenen numunelerde UV bloklama özelliği ile kırınım indisindeki artış elde edilmiştir. 


\section{TEŞEKKÜR}

Bu çalışma Sn. Mine Şener'in Yüksek Lisans tez çalışması olarak tamamlanmış aynı zamanda kısmen Cumhuriyet Üniversitesi Bilimsel Araştırma Destekleme Programı'nca M696 numaralı proje olarak desteklenmiştir.

\section{KISALTMALAR}

$\begin{array}{llll}\text { AFM } & \text { Atomik Kuvvet Mikroskobu/ Mikroskobisi } & \text { BPO } & \text { Benzoil peroksit } \\ \text { EGDMA } & \text { Etilen glisidil metakrilat } & \text { FS } & \text { MA } \\ \text { HEMA } & \text { 2-hidroksietil metakrilat } & & \text { Metakrilat } \\ \text { MMA } & \text { Metil metakrilat } & \end{array}$

\section{KAYNAKLAR}

[1] Musgrave, C.S.A. and F. Fang, contact lens materials: A materials science perspective. Materials (Basel, Switzerland), 2019. 12(2): p. 261.

[2] Ali, U., K.J.B.A. Karim, and N.A. Buang, A review of the properties and applications of poly (methyl methacrylate) (PMMA). Polymer Reviews, 2015. 55(4): p. 678-705.

[3] Kopeček, J., Hydrogels from soft contact lenses and implants to self-assembled nanomaterials. Journal of polymer science. Part A, Polymer Chemistry, 2009. 47(22): p. 5929-5946.

[4] Guillon, M., Are silicone hydrogel contact lenses more comfortable than hydrogel contact lenses? Eye Contact Lens, 2013. 39(1): p. 86-92.

[5] Edrington, T.B., A literature review: The impact of rotational stabilization methods on toric soft contact lens performance. Contact Lens and Anterior Eye, 2011. 34(3): p. 104-110.

[6] Newlove, D., Contact lens manufacture - A world review. Journal of The British Contact Lens Association, 1982. 5(1): p. 2-14.

[7] Kim, E., M. Saha, and K. Ehrmann, Mechanical properties of contact lens materials. Eye \& Contact Lens, 2018. 44: p. S148-S156.

[8] Oliver, W.C. and G.M. Pharr, An improved technique for determining hardness and elastic modulus using load and displacement sensing indentation experiments. Journal of Materials Research, 1992. 7(06): p. 15641583.

[9] Pharr, G.M., Measurement of mechanical properties by ultra-low load indentation. Materials Science and Engineering: A, 1998. 253(1): p. 151-159.

[10] Qian, L., et al., Comparison of nano-indentation hardness to microhardness. Surface and Coatings Technology, 2005. 195(2): p. 264-271.

[11] Tuck, J.R., et al., Indentation hardness evaluation of cathodic arc deposited thin hard coatings. Surface and Coatings Technology, 2001. 139(1): p. 63-74.

[12] Luna, M., D.F. Ogletree, and M. Salmeron, A study of the topographic and electrical properties of selfassembled islands of alkylsilanes on mica using a combination of non-contact force microscopy techniques. Nanotechnology, 2006. 17(7): p. S178-84. 
[13] Calabri, L., et al., AFM nanoindentation: tip shape and tip radius of curvature effect on the hardness measurement. Journal of Physics: Condensed Matter, 2008. 20(47): p. 474208.

[14] Vahabi, S., B. Nazemi Salman, and A. Javanmard, Atomic force microscopy application in biological research: a review study. Iranian journal of medical sciences, 2013. 38(2): p. 76-83.

[15] Ding, Y., G.-K. Xu, and G.-F. Wang, On the determination of elastic moduli of cells by AFM based indentation. Scientific Reports, 2017. 7: p. 45575.

[16] Stark, R.W., et al., Determination of elastic properties of single aerogel powder particles with the AFM. Ultramicroscopy, 1998. 75(3): p. 161-169.

[17] Roa, J.J., et al., Calculation of Young's modulus value by means of AFM. Recent Patents on Nanotechnology, 2011. 5(1): p. 27-36.

[18] Ferencz, R., et al., AFM nanoindentation to determine Young's modulus for different EPDM elastomers. Polymer Testing, 2012. 31(3): p. 425-432.

[19] Caglayan, M.O., Nanomechanical characterization of flowable dental restorative nanocomposite resins using AFM. Polymer-Plastics Technology and Engineering, 2017. 56(16): p. 1813-1821.

[20] Caglayan, M.O., Atomic force microscopy as a characterization tool for contact lenses: Indentation tests and grain analysis. International Journal of Polymeric Materials and Polymeric Biomaterials, 2014. 63(13): p. 680-684.

[21] Küçükoflaz, M., B. Saraçoğlu Kaya, and M.O. Caglayan, Determination of mechanical properties of polymeric microspheres used in controlled drug delivery systems by nanoindentation. Polymer-Plastics Technology and Materials, 2019. 58(7): p. 765-775.

[22] Jain, P.K., et al., Calculated absorption and scattering properties of gold nanoparticles of different size, shape, and composition: Applications in Biological Imaging and Biomedicine. The Journal of Physical Chemistry B, 2006. 110(14): p. 7238-7248. 